\title{
Relationship between body condition score and health traits in first-lactation Canadian Holsteins
}

\author{
S. Loker, ${ }^{11,2}$ F. Miglior,†‡ A. Koeck, ${ }^{\star}$ T. F.-O. Neuenschwander,§ C. Bastin,\# J. Jamrozik, ${ }^{\star}$ L. R. Schaeffer, ${ }^{\star}$ \\ and D. Keltonll \\ ${ }^{*}$ Centre for Genetic Improvement of Livestock, Department of Animal \& Poultry Science, University of Guelph, Guelph, Ontario, \\ Canada, N1G 2W1 \\ †Guelph Food Research Centre, Agriculture and Agri-Food Canada, Guelph, Ontario, Canada, N1G 5C9 \\ ¥Canadian Dairy Network, Guelph, Ontario, Canada, N1K 1E5 \\ §LINEAR SA, Posieux, Switzerland, $\mathrm{CH}-1725$ \\ \#University of Liège, Gembloux Agro-Bio Tech, B-5030 Gembloux, Belgium \\ IIDepartment of Population Medicine, Ontario Veterinary College, University of Guelph, Guelph, Ontario, Canada, N1G 2W1
}

\section{ABSTRACT}

The objective of this research was to estimate daily genetic correlations between longitudinal body condition score (BCS) and health traits by using a random regression animal model in first-lactation Holsteins. The use of indicator traits may increase the rate of genetic progress for functional traits relative to direct selection for functional traits. Indicator traits of interest are those that are easier to record, can be measured early in life, and are strongly genetically correlated with the functional trait of interest. Several BCS records were available per cow, and only 1 record per health trait $(1=$ affected; $0=$ not affected $)$ was permitted per cow over the lactation. Two bivariate analyses were performed, the first between BCS and mastitis and the second between BCS and metabolic disease (displaced abomasum, milk fever, and ketosis). For the first analysis, 217 complete herds were analyzed, which included 28,394 BCS records for 10,715 cows and 6,816 mastitis records for 6,816 cows. For the second analysis, 350 complete herds were analyzed, which included 42,167 BCS records for 16,534 cows and 13,455 metabolic disease records for 13,455 cows. Estimation of variance components by a Bayesian approach via Gibbs sampling was performed using 400,000 samples after a burn-in of 150,000 samples. The average daily heritability (posterior standard deviation) of BCS was 0.260 (0.026) and the heritabilities of mastitis and metabolic disease were 0.020 (0.007) and 0.041 (0.012), respectively. Heritability estimates were similar to literature values. The average daily genetic correlation between $\mathrm{BCS}$ and mastitis was $-0.730(0.110)$. Cows with a

\footnotetext{
Received April 11, 2012.

Accepted July 25, 2012.

${ }^{1}$ Corresponding author: sloker@lic.co.nz

${ }^{2}$ Current address: Livestock Improvement Co., 605 Ruakura Rd., Newstead, Hamilton, New Zealand.
}

low BCS during the lactation are more susceptible to mastitis, and mastitic cows are likely to have low BCS. Daily estimates of genetic correlations between BCS and mastitis were moderate to strong throughout the lactation, becoming stronger as the lactation progressed. The average daily genetic correlation between BCS and metabolic disease was -0.438 (0.125), and was consistent throughout the lactation. A lower BCS during the lactation is genetically associated with the occurrence of mastitis and metabolic disease.

Key words: body condition score, health trait, genetic correlation, random regression model

\section{INTRODUCTION}

Dairy cattle selection over the last $50 \mathrm{yr}$ has prioritized milk production at the expense of health and fertility (Veerkamp et al., 2001; Heringstad et al., 2003; Dillon, 2006). Since the early 2000s, countries have been placing more emphasis on the selection of functional traits (Miglior et al., 2005; Neuenschwander, 2010). Although health and fertility traits are economically important and they possess sufficient genetic variation to allow for selection (Emanuelson et al., 1988; Shook, 1989; Weigel and Rekaya, 2000), they have low heritability (Wall et al., 2003; Neuenschwander, 2010; Koeck et al., 2011a,b, 2012a,b; Neuenschwander et al., 2012), are difficult to measure (Dal Zotto et al., 2007; Bastin et al., 2010a), and are susceptible to data quality issues (Kadarmideen and Coffey, 2001; Wall et al., 2003; Neuenschwander, 2010; Neuenschwander et al., 2012). Therefore, the use of indicator traits (traits used to indicate an animal's genetic merit for another trait) may result in a faster rate of genetic progress for health and fertility.

Energy balance is a candidate indicator trait of health and fertility status. Wathes et al. (2007) discussed how excessive tissue mobilization attributable to a negative energy balance can be considered a metabolic disorder 
affecting high-yielding cows such that health and fertility functions are impaired. A study by Collard et al. (2000) determined that a longer, more extreme period of negative energy balance was associated with digestive (including displaced abomasum, milk fever, and ketosis) and locomotion problems. Grummer (1993) concluded that intense mobilization of adipose tissue as a result of a severe negative energy balance in early lactation can lead to the development of fatty liver syndrome and ketosis. Early-lactation negative energy balance may compromise the recovery of the uterus and result in metabolic changes that affect ovarian function and early embryo development (Wathes et al., 2007). A negative energy balance affects the size and ovulatory fate of the first dominant follicle and increases postpartum anoestrous (Beam and Butler, 1997; Diskin et al., 2003). Harrison et al. (1990) found an antagonistic relationship between increased negative energy balance attributable to high milk production and the expression of estrous behavior.

Direct measures of energy balance are primarily based on individual cow feed intake and milk output (Veerkamp et al., 2000; Hüttmann et al., 2009). However, measurement of individual feed intake is expensive (Veerkamp et al., 2000; Hüttmann et al., 2009) and unfeasible in a commercial population (Banos and Coffey, 2010). Body condition score is a subjective measure of the tissue reserves available on an animal (Edmonson et al., 1989), and is therefore an indicator of energy balance. It has been widely used as a management tool for producers to monitor and manage the nutritional, health, and fertility status of their herds (Wildman et al., 1982; Gearhart et al., 1990; Bewley and Schutz, 2008).

More specifically, BCS is an estimate of fat stores on the body (Ferguson et al., 1994) assessing subcutaneous fat cover over specific body regions (Wright and Russel, 1984). Wright and Russel (1984) found that BCS is a poor predictor of inter- and intramuscular fat, which together account for 35 to $45 \%$ of body fat (Roche et al., 2009). However, the proportion of subcutaneous fat is highly correlated with total body fat (Butler-Hogg et al., 1985) such that BCS is more useful as an assessment of a relative, rather than absolute, change in body fat (Gregory et al., 1998). Body condition score may be less accurate in thin cows with little subcutaneous fat, and it may be more difficult to assess subcutaneous fat levels accurately in obese cows (Roche et al., 2009). Nevertheless, fewer animals are at the extremes of the BCS scale (Ruegg and Milton, 1995; Roche et al., 2004; Berry et al., 2007), and Schröder and Staufenbiel (2006) summarized from various studies that a 1-unit change in BCS consistently correlated with about $50 \mathrm{~kg}$ of empty body fat. Additionally, Waltner et al. (1994) reported a strong correlation between BCS and observed body fat. Conversely, other studies have linked the rarity of animals with BCS at the extremes with a reluctance to score near the end points (Kristensen et al., 2006) or a fear of offending the producer (Ward, 2003, as referred to by Bewley and Schutz, 2008).

Several studies have indicated that, although it is a subjectively measured trait, BCS is accurate enough to explain a large part of the variation in body reserves between animals (Waltner et al., 1994; Enevoldsen and Kristensen, 1997; Gregory et al., 1998). Body condition score meets all the criteria to be considered a useful indicator trait for health and fertility status in dairy cattle. Several studies have found that BCS has a moderate heritability, ranging between 0.20 and 0.51 , with the majority of studies estimating heritability between 0.20 and 0.30 [Jones et al., 1999; Veerkamp et al., 2001; Berry et al., 2003b; Loker et al., 2011, 2012; S. Loker, C. Bastin, F. Miglior, A. Sewalem, L. R. Schaeffer, J. Jamrozik, V. Osborne (Centre for Nutrition Modelling, University of Guelph, Guelph, ON, Canada), and A. Ali (Department of Mathematics and Statistics, University of Guelph, Guelph, ON, Canada), unpublished data], which indicates that the trait can be recorded consistently with less environmental influence relative to traits with low heritability. Body condition score possesses ample genetic variation throughout lactation to allow for successful selection (Veerkamp et al., 2001; Berry et al., 2003b; Mao et al., 2004; Loker et al., 2011). Because the body condition can be scored visually on freely moving cattle (Edmonson et al., 1989), it is easy, quick, and inexpensive to measure (Waltner et al., 1994). Last, BCS is moderately to strongly genetically correlated with health (Dechow et al., 2004; Neuenschwander, 2010) and reproduction status (Pryce et al., 2001; Banos and Coffey, 2010; Bastin et al., 2010a,b). In Canada, collection of BCS is part of a routine type classification system, so sufficient data would be available nationwide if a genetic evaluation for this trait were developed. Currently, several countries include BCS in genetic evaluations, including Belgium, the Czech Republic, Denmark, Germany, France, Switzerland, and the United Kingdom, although none evaluate the trait with a random regression model (Interbull, 2012).

Recent Canadian research on BCS (Bastin et al., 2010a,b; Neuenschwander, 2010; Loker et al., 2011, 2012; Neuenschwander et al., 2012; ) used data provided by Valacta, a Canadian milk recording agency based in Sainte-Anne-de-Bellevue, Québec, Canada. The research supported the development of a genetic evaluation of BCS in Canada by using a random regression animal model, which would allow each animal to be ranked according to a unique BCS lactation curve. A BCS genetic evaluation could be used to improve 
health and fertility traits indirectly. Neuenschwander (2010) investigated the change in genetic correlations between BCS and health traits on a month-to-month basis by using a random regression sire model. Bastin et al. (2010a) investigated the change in genetic correlation between longitudinal BCS and fertility traits on a daily basis over the lactation by using a random regression animal model. No other studies have investigated the change in genetic correlations between BCS and health traits on a daily basis when using a random regression animal model. The objective of the current study was to analyze longitudinal BCS with mastitis and metabolic diseases (displaced abomasum, milk fever, and ketosis) by using a random regression animal model.

\section{MATERIALS AND METHODS}

\section{Edits Specific to BCS Data}

First-lactation BCS records from 1998 to 2010 were available, collected from Québec herds by Valacta (Sainte-Anne-de-Bellevue, QC, Canada). Data were extracted from the Canadian Dairy Network (Guelph, ON, Canada). From 1 to 14 BCS records were collected per cow (average of 2.5). Body condition score was recorded on a scale from 1 (thin) to 5 (fat) in increments of 0.25, based on the methodology of Edmonson et al. (1989). Because health data were available from April 2007 onward, BCS data before April 2007 were removed. To remove herds for which BCS was not recorded reliably, herds had to have a BCS standard deviation of $\geq 0.25$. Records were restricted to those taken between 5 and $335 \mathrm{~d}$ after calving. Age at calving was restricted to 19 to 40 mo. Body condition score records in classes of herd $\times$ scoring date with $<5$ records were deleted. In accordance with the distribution of the data, 4 age-at-calving classes were formed $(\leq 24,25$ to 26,27 to 28 , and $\geq 29 \mathrm{mo}$ ), and 3 yr-of-calving classes were formed (2006 to 2007, 2008, 2009 to 2010). Four seasons of calving (January to March, April to June, July to September, October to December) were defined. These were used to form age $\times$ year $\times$ season of calving classes, and herd $\times$ calving year classes $(\mathbf{H Y})$.

\section{Edits Specific to Health Data}

Producer-recorded health data were available from 2007 to 2011 via the Canadian Dairy Network. Firstlactation health records were kept. Mastitis, displaced abomasum, milk fever, and ketosis were binary traits ( 1 = affected; 0 = not affected). Displaced abomasum, milk fever, and ketosis are all metabolic diseases with a similar etiology (Neuenschwander, 2010) and each had a low frequency of occurrence; hence, they were grouped together. For each disease (mastitis or metabolic disease), herds had to have at least 2 recorded cases (occurring between 0 and $335 \mathrm{~d}$ after calving) to be included in the analysis. Additionally, the first and last cases had to be at least $180 \mathrm{~d}$ apart. This ensured the inclusion of herds that were recording the diseases reliably and for a reasonable period. Cows in these herds that were never recorded as having mastitis or a metabolic disease were assumed to be healthy and were assigned a 0 for that disease record. If cows had repeated records for a health trait in the lactation, only the first record for that trait was kept. To ensure continuous data recording, herds had to have a minimum mastitis frequency of $5 \%$ per year during the period between the first and last recorded mastitis case. For the metabolic disease analysis, herds had to have a minimum frequency of occurrence of $1 \%$ per year during the period between the first and last case. Age at calving was restricted to 19 to $40 \mathrm{mo}$. In accordance with the distribution of the health data, 16 age-at-calving classes were formed, with 1 mo per class and ages $<22$ mo and $>35$ mo grouped into 1 class each. Four seasons of calving (January to March, April to June, July to September, October to December) were defined. Enough health records per year of calving were available to allow 1 yr of calving in each year of calving class (from 2007 to 2010). Year $\times$ season and herd $\times$ year $\times$ season (HYS) of calving classes were then formed. Classes of HYS with $<3$ records were removed from the analysis. Because the frequency of mastitis records was reduced drastically by late lactation, mastitis records (either 1 or 0 ) were limited to those occurring $\leq 150 \mathrm{~d}$ after calving. Likewise, because the frequency of metabolic disease occurrence was reduced drastically after early lactation, metabolic disease records were limited to those occurring $\leq 50 \mathrm{~d}$ after calving.

Two bivariate analyses were run, one that analyzed mastitis with BCS and another that analyzed metabolic disease with BCS. For each bivariate analysis, herds had to have a minimum of 30 animals, and $85 \%$ of the sires associated with a herd had to have daughters in both the BCS and health data sets. This ensured consistent overlap between data sets. After editing, 217 acceptable herds were left for the BCS and mastitis analysis, and 350 acceptable herds were left for the BCS and metabolic disease analysis. Data were merged by animal and observation date. For the first analysis, 28,394 BCS records were available for 10,715 cows, and 6,816 mastitis records were available for 6,816 cows. In total, 4,719 cows had records in both the BCS and mastitis data sets. In total, 1,168 sires had daughters with BCS records, and 900 sires had daughters with records in the mastitis data set; 844 sires had daughters 


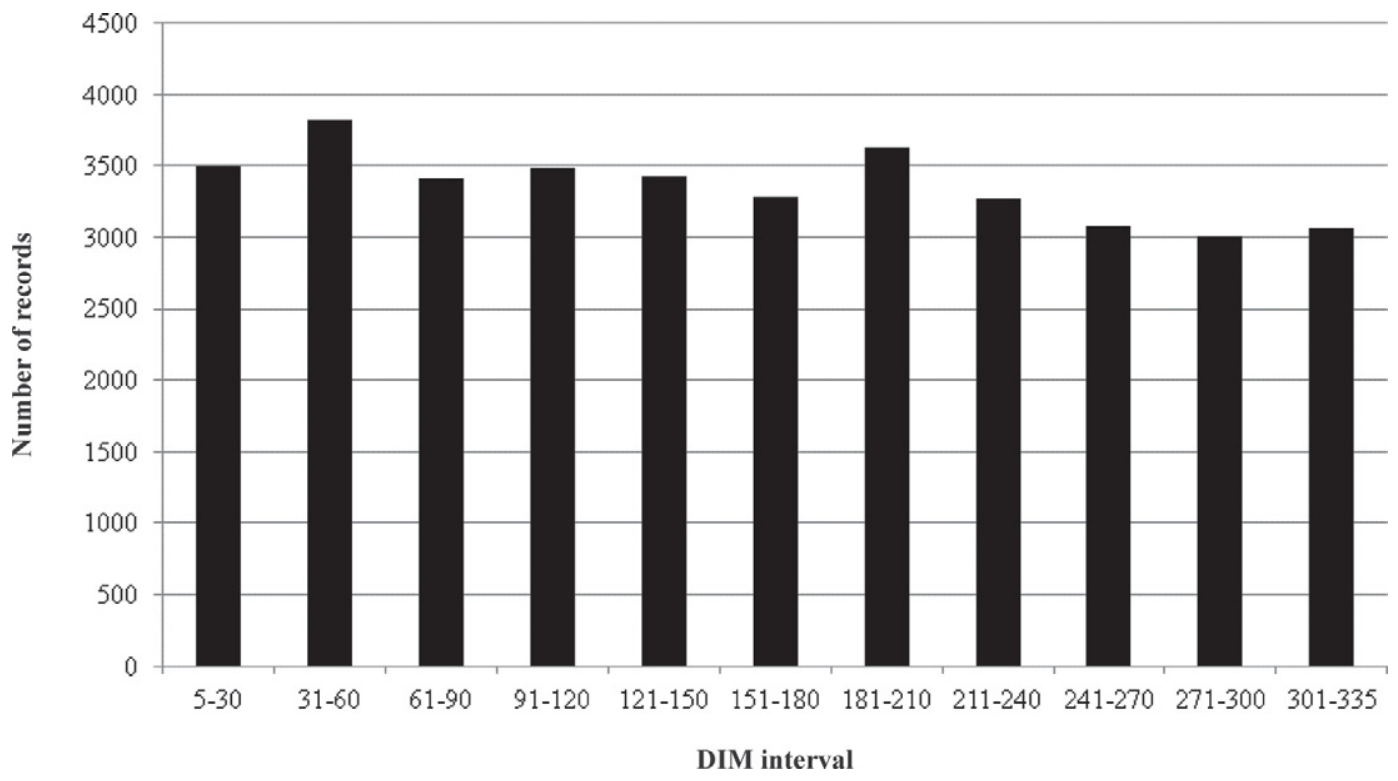

Figure 1. Average distribution of BCS records for each DIM interval across the first lactation.

in both the BCS and mastitis data sets. The average BCS was $2.68 \pm 0.44$, and the frequency of mastitis occurrence (from 5 to 150 DIM) was $10.1 \%$. For the second analysis, 42,167 BCS records were available for 16,534 cows and 13,455 metabolic disease records were available for 13,455 cows. In total, 8,788 cows had records in both the BCS and metabolic disease data sets; 1,386 sires had daughters with BCS records, and 1,114 sires had daughters with records in the metabolic disease data set. In total, 1,034 sires had daughters in both the BCS and metabolic disease data sets. The average BCS was $2.66 \pm 0.44$, and the frequency of metabolic disease occurrence (from 5 to 50 DIM) was $4.5 \%$. Figure 1 displays the distribution of BCS records across lactation (averaged from the BCS records available for both bivariate analyses). Figures 2 and 3 show the distribution over time of mastitis and metabolic disease events, respectively.

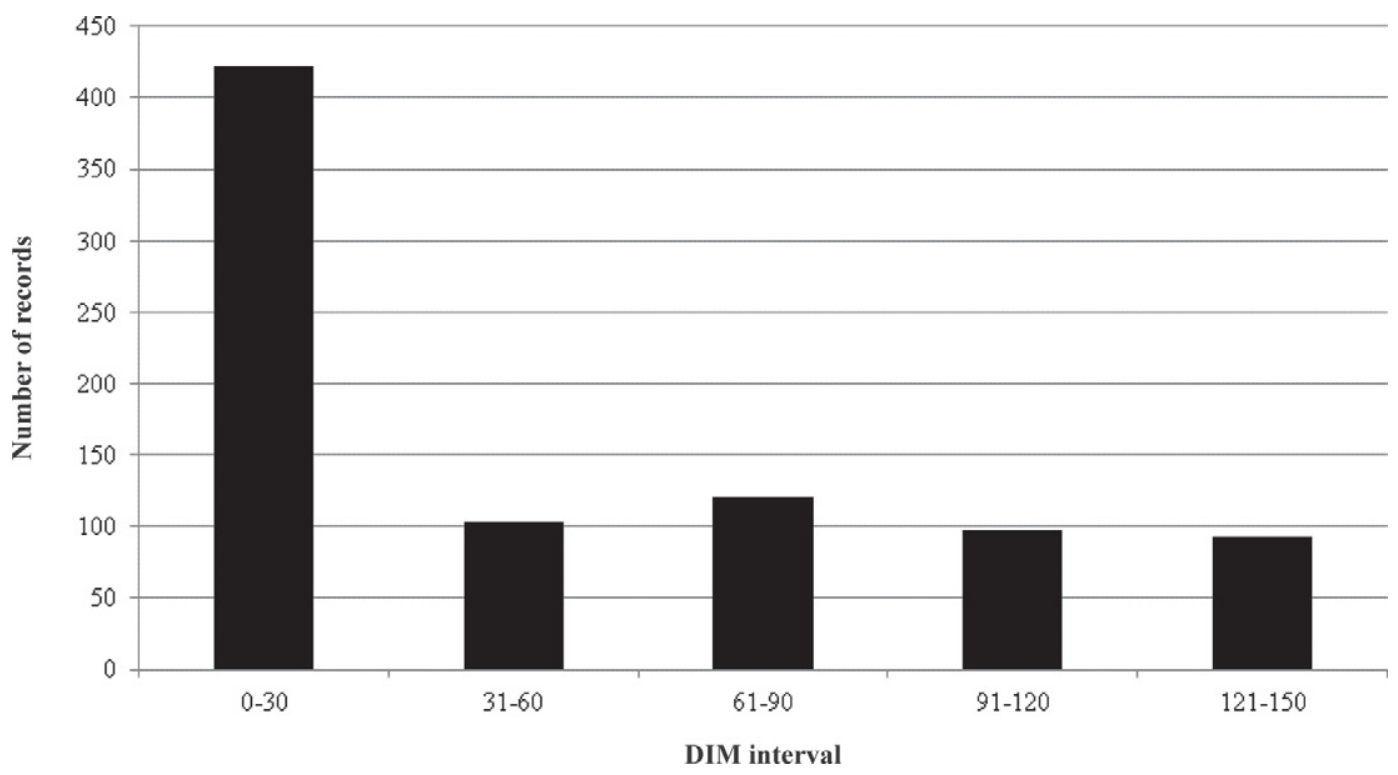

Figure 2. Distribution of mastitis events recorded within each DIM interval from 0 to 150 DIM. 


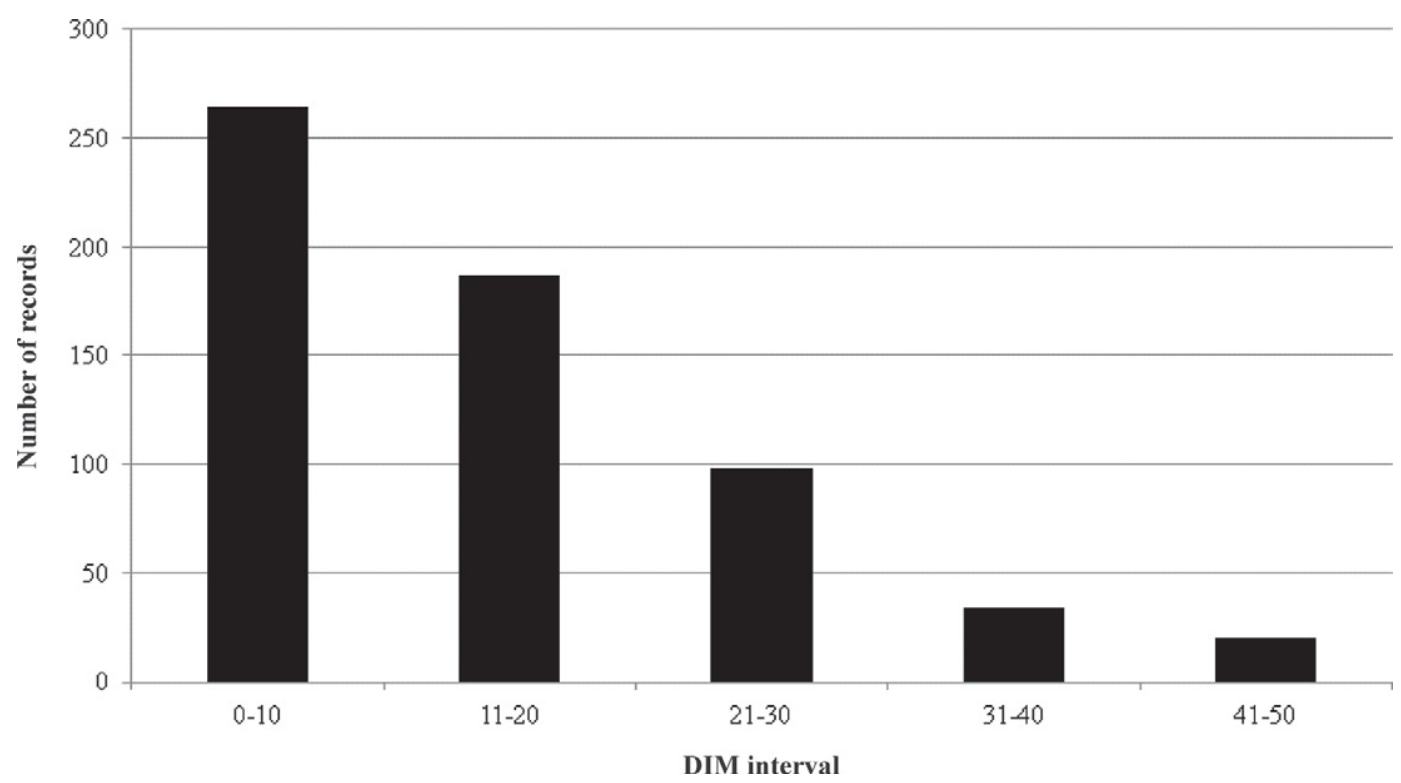

Figure 3. Distribution of metabolic disease (displaced abomasum, milk fever, and ketosis) events recorded within each DIM interval from 0 to 50 DIM.

For BCS records from 5 to 335 DIM, the following model was used:

$$
\mathbf{y}=\mathbf{X} \boldsymbol{\beta}+\mathbf{Z}_{1} \mathbf{h}+\mathbf{Z}_{2} \mathbf{a}+\mathbf{Z}_{3} \mathbf{p}+\mathbf{e}
$$

where $\boldsymbol{\beta}$ was the vector of fixed herd $\times$ scoring date effects, and of fixed regression coefficients for age $\times$ year $\times$ season effects; $\mathbf{h}$ was the vector of random regression coefficients for HY effects; a was the vector of random regression coefficients for additive genetic effects; $\mathbf{p}$ was the vector of random regression coefficients for permanent environmental (PE) effects; $\mathbf{e}$ was a vector of random residuals; and $\mathbf{X}, \mathbf{Z}_{1}, \mathbf{Z}_{2}$, and $\mathbf{Z}_{3}$ were incidence matrices assigning observations to effects.

For mastitis records from 1 to 150 DIM and metabolic disease records from 5 to 50 DIM, the following model was used:

$$
\mathbf{y}=\mathbf{X} \boldsymbol{\beta}+\mathbf{Z}_{4} \mathbf{h y s}+\mathbf{Z}_{2} \mathbf{a}+\mathbf{Z}_{3} \mathbf{p}+\mathbf{e}
$$

where $\boldsymbol{\beta}$ was the vector of fixed age-at-calving effects and year $\times$ season effects; hys was the vector of the random HYS effects; a was the vector of random additive genetic effects; $\mathbf{p}$ was the vector of random environmental effects, accounting for common, nongenetic, animal-specific environmental effects in common with BCS; e was a vector of random residuals; and $\mathbf{X}, \mathbf{Z}_{4}$, $\mathbf{Z}_{2}$, and $\mathbf{Z}_{3}$ were incidence matrices assigning observations to effects. Justification for the use of a linear model over a threshold model for these binary health traits is presented in the Results and Discussion section of the paper.

Legendre polynomials of the second order were used to describe regression curves for BCS. As in the studies by Negussie et al. (2008b), Bastin et al. (2010a), and Loker et al. (2012), within-animal environmental covariance among traits was modeled by the PE effect. This effect allowed for a cow-specific, nongenetic link between BCS and health traits. Additionally, residual covariances between BCS and health traits were set to zero because the traits of the 2 data sets were recorded from 2 separate systems, and any residuals were assumed to be independent.

The expectations and covariance structure for the random effects were

$$
\begin{gathered}
\mathrm{E}(\mathbf{y})=\mathbf{X} \boldsymbol{\beta}, \mathrm{E}(\mathbf{h})=0, \mathrm{E}(\mathbf{h y s})=0, \mathrm{E}(\mathbf{a})=0, \\
\mathrm{E}(\mathbf{p})=0, \mathrm{E}(\mathbf{e})=0
\end{gathered}
$$

and

$$
\begin{gathered}
\mathrm{V}\left(\mathbf{h}_{1}\right)=\mathbf{I} \otimes \mathbf{Q}_{0}, \mathrm{~V}(\mathbf{h y s})=\mathbf{I} \otimes \mathbf{T}_{0}, \mathrm{~V}(\mathbf{p})=\mathbf{I} \otimes \mathbf{P}_{0} \\
\mathrm{~V}(\mathbf{a})=\mathbf{A} \otimes \mathbf{G}_{0}, \mathrm{~V}(\mathbf{e})=\mathbf{E}
\end{gathered}
$$

where $\otimes$ is the Kronecker product (Searle, 1982), I represents an identity matrix, $\mathbf{A}$ is the additive relationship matrix, $\mathbf{Q}_{0}$ is a (co)variance matrix for $\mathrm{HY}$ regression coefficients, $\mathbf{T}_{0}$ is a (co)variance matrix for HYS random effects, and $\mathbf{P}_{0}$ and $\mathbf{G}_{0}$ are (co)variance 
matrices for $\mathrm{PE}$ and additive genetic regression coefficients, respectively. Matrix $\mathbf{E}$ is the residual (co)variance matrix with the residual covariance between BCS, and with mastitis or metabolic disease set to zero. All random effects were assumed to be normally distributed.

Variance components were estimated using DMU software (Madsen and Jensen, 2008) by a Bayesian approach via Gibbs sampling. Prior values were set arbitrarily to 0.03 for variances and 0 for covariances. Posterior means of (co)variance components were estimated using 400,000 samples after a burn-in of 150,000 samples. The convergence of the Gibbs sampler was monitored by visual inspection of the plot of realizations for selected covariance components.

Daily heritability for BCS was defined as the ratio of additive genetic variance to phenotypic variance on a given DIM. Average daily heritability for BCS, genetic correlations, and variances for BCS were obtained by summing daily heritabilities, genetic correlations, or variances from 5 to 335 DIM and dividing by 331 . Because BCS was included in 2 analyses, 2 average daily heritabilities were calculated for this trait. These 2 heritabilities were then averaged to produce an overall average daily heritability. The same procedure was used for calculating average daily genetic correlations and BCS average daily genetic, $\mathrm{PE}, \mathrm{HY}$, and residual variances. Parameter estimates are presented with posterior standard deviations in parentheses.

\section{RESULTS AND DISCUSSION}

The daily heritability, and genetic and PE variance of BCS were similar to previous work analyzing longitudinal BCS (Loker et al., 2011). The genetic variance of BCS was slightly higher for the mastitis analysis compared with the metabolic disease analysis (Figure 4 ), which caused the heritability of BCS to be slightly higher in that analysis $[0.274(0.030)$ in the mastitis analysis and $0.246(0.023)$ in the metabolic disease analysis; shown in Figure 5 on a daily basis]. The PE, $\mathrm{HY}$, and residual variances for BCS were very similar between the 2 analyses, on an average daily basis and on a daily basis (results not shown). Average daily heritability and genetic, PE, HY, and residual variances (averaged across both analyses) for BCS are displayed in Table 1. Posterior standard deviations (Table 1) were very low, ranging from 0.0003 to 0.03 . Average daily heritability for BCS was 0.260 (0.026), which was within the range of literature values (Jones et al., 1999; Koenen et al., 2001; Berry et al., 2003b; Loker et al., 2011, 2012).

Genetic, PE, HYS, and residual variances for mastitis and metabolic disease are displayed in Table 1.

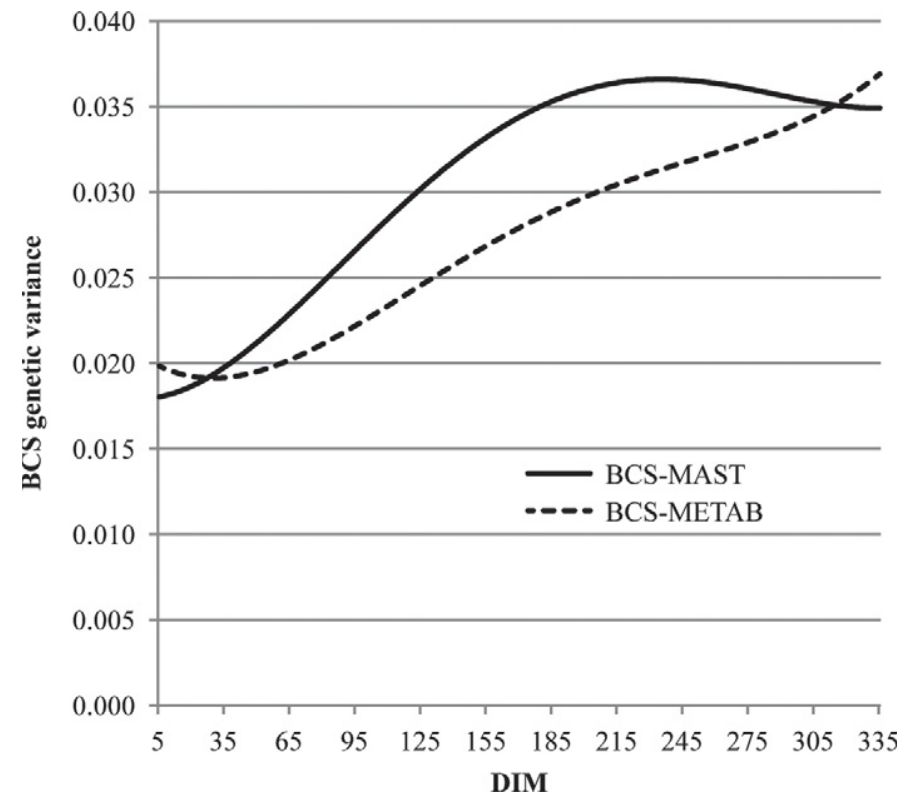

Figure 4. Estimates of daily genetic variances for BCS analyzed in a bivariate model with either mastitis (MAST) or metabolic disease (METAB).

Heritability for mastitis was 0.020 (0.007), which closely follows the heritability obtained by other studies using the same mastitis data source (Neuenschwander, 2010; Koeck et al., 2011a,b, 2012a,b; Neuenschwander et al., 2012). Heritability for metabolic disease was 0.041 (0.012), which was higher than that reported by Neuenschwander (2010), who obtained a heritability below

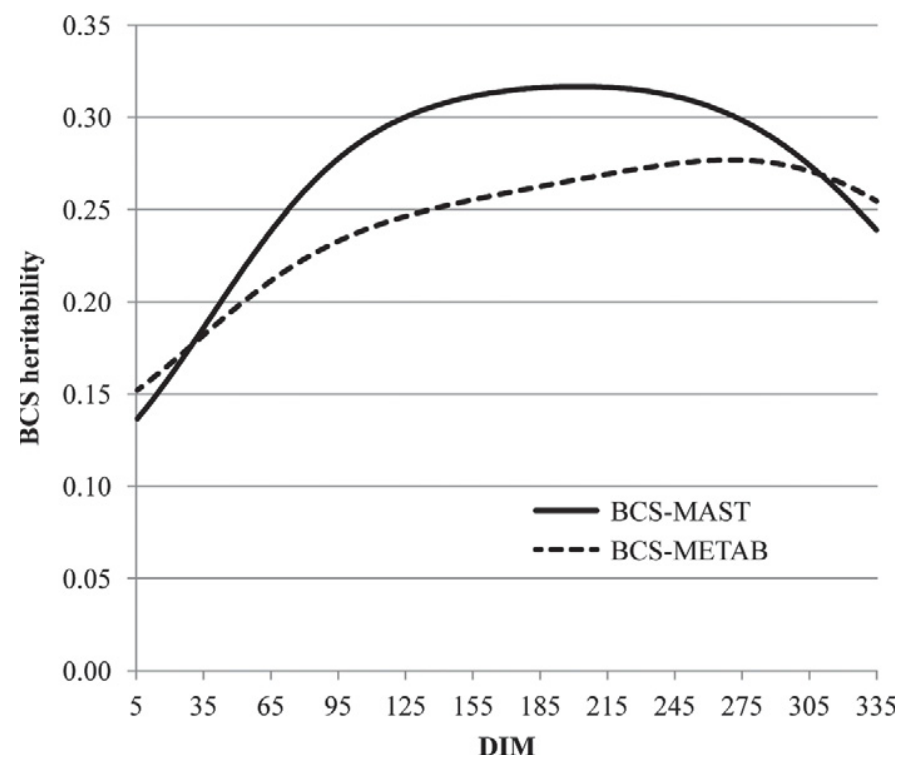

Figure 5. Estimates of daily heritability for BCS analyzed in a bivariate model with either mastitis (MAST) or metabolic disease (METAB). 
Table 1. Heritability $\left(\mathrm{h}^{2}\right)$ and variance parameters for BCS, mastitis, and metabolic disease (posterior SD in parentheses)

\begin{tabular}{lccl}
\hline Item $^{1}$ & BCS & Mastitis & $\begin{array}{c}\text { Metabolic } \\
\text { disease }\end{array}$ \\
\hline $\mathrm{h}^{2}$ & $0.260(0.026)$ & $0.020(0.007)$ & $0.041(0.012)$ \\
$\sigma^{2}$ & $0.029(0.003)$ & $0.002(0.001)$ & $0.002(0.0005)$ \\
$\sigma^{2}{ }^{2}$ & $0.043(0.002)$ & $0.030(0.017)$ & $0.013(0.007)$ \\
$\sigma_{{ }^{\mathrm{Pe}}}^{\mathrm{HY}}$ & $0.008(0.001)$ & - & - \\
$\sigma^{2} \mathrm{HYS}$ & - & $0.006(0.001)$ & $0.002(0.0003)$ \\
$\sigma_{\text {RES }}^{2}$ & $0.031(0.0004)$ & $0.053(0.017)$ & $0.026(0.007)$ \\
\hline
\end{tabular}

${ }^{1} \sigma_{a}^{2}=$ additive genetic variance, $\sigma_{p e}^{2}=$ permanent environmental variance, $\sigma_{\mathrm{HY}}^{2}=$ herd $\times$ year variance, $\sigma_{\mathrm{HYS}}^{2}=$ herd $\times$ year $\times$ season variance, and $\sigma_{\text {RES }}^{2}=$ residual variance.

0.02 for metabolic disease. Neuenschwander (2010) analyzed health traits with BCS and used the same source of health data, although they had about $1.5 \mathrm{yr}$ of health data (compared with the 4 yr used in the current study) and analyzed the traits with both a linear sire model and a random regression sire model, with covariates formed using month in milk when the record was taken. Thus, differences in results were expected between that investigation and the current one. Using the same source of health data, recorded between 2007 and 2011, Koeck et al. (2011a) analyzed BCS in bivariate analyses with displaced abomasum and ketosis by using linear animal models and obtained heritabilities of $0.07(\mathrm{SE}=0.009)$ and $0.03(\mathrm{SE}=0.008)$ for each health trait, respectively.

For the first analysis, mastitis records were limited to 150 DIM. When mastitis records up to 335 DIM were included in the analysis, heritabilities were 0.276 (0.030) and 0.032 (0.011) for BCS and mastitis, respectively, which were similar to those estimated when mastitis was limited to 150 DIM. However, when mastitis records up to 335 DIM were included in the analysis, the average daily genetic correlation between BCS and mastitis was $-0.559(0.167)$ and did not appear to converge when samples were plotted and investigated visually. During the period of 5 to $335 \mathrm{~d}$ after calving, the frequency of cows diagnosed with mastitis was $14.0 \%$. Most of the mastitis cases occurred within the first 150 DIM, and the proportion of mastitic cows relative to healthy cows became very low by the end of lactation (e.g., $0.4 \%$ in the 11th month after calving). We assumed that after about 150 DIM, the data structure had changed enough such that samples of the genetic correlation between BCS and mastitis would not converge. When mastitis was limited only to events at $\leq 150$ DIM, genetic correlations between BCS and mastitis converged at about 150,000 rounds of Gibbs sampling, based on visual inspection.

The Canadian Holstein population is generally too thin (Loker et al., 2011). For instance, for the BCS and mastitis data set, only 20 cows had BCS $>4.0$ in the first 100 DIM, and only 14 of those had a mastitis record of either 0 or 1 . Therefore, cows with BCS $\leq 2.0$ and cows with BCS $>2.0$ were compared phenotypically. Cows with an average BCS $\leq 2.0$ in the first 100 DIM had an incidence of mastitis of $8.53 \%$, and those with BCS $>2.0$ had an incidence of mastitis of $10.40 \%$. Although the difference in mastitis incidence between thin and not-thin cows was small, the thin cows were expected to have a greater incidence. Typically, very fat or very thin cows are at a greater risk of disease in the first 100 DIM (Lassen et al., 2003).

Figure 6 is the plot of convergence of the average daily genetic correlation between BCS and mastitis calculated by using genetic (co)variance estimates from every fifth round of the Gibbs sampler. The average daily genetic correlation between BCS and mastitis was -0.730 (0.110). Daily genetic correlations between BCS and mastitis are shown in Figure 7. Daily estimates of genetic correlations between BCS and mastitis were moderate to strong throughout the lactation, becoming stronger as lactation progressed. Using a random regression sire model, Neuenschwander (2010) obtained a genetic correlation between BCS and mastitis occurrence of about -0.30 throughout the majority of the lactation. Using a linear animal model, with BCS and mastitis recorded once per cow, Koeck et al. (2011a) obtained a genetic correlation of $-0.35(\mathrm{SE}=0.10)$ between BCS and mastitis. Using a sire model, with a fixed regression of DIM at classification for BCS and only mastitis records before 50 DIM, Lassen et al. (2003) obtained a genetic correlation of $-0.16(\mathrm{SE}=$ 0.09 ) between BCS and mastitis. The much stronger genetic correlation between BCS and mastitis in this study may be due to the use of a random regression animal model, which was not used in other studies.

Similar to mastitis, the occurrence of metabolic disease became infrequent as the lactation progressed. The majority of metabolic disease records occurred before 50 DIM, so to avoid convergence problems for estimation of the genetic correlation with BCS, metabolic disease events after 50 DIM were removed. Based on visual inspection, 150,000 rounds of Gibbs sampling was found to be a sufficient burn-in period for convergence of parameter estimates.

For the BCS and metabolic disease data set, only 30 cows had BCS >4.0 in the first 100 DIM, and only 19 of those had a metabolic disease record of either 0 or 1. Therefore, cows with BCS $\leq 2.0$ and cows with BCS $>2.0$ were compared phenotypically. Cows with an average BCS $\leq 2.0$ in the first 100 DIM had an incidence of metabolic disease of $7.99 \%$, and those with BCS $>2.0$ had an incidence of metabolic disease of $3.81 \%$.

Figure 8 is the plot of convergence of average daily genetic correlation between BCS and metabolic disease 


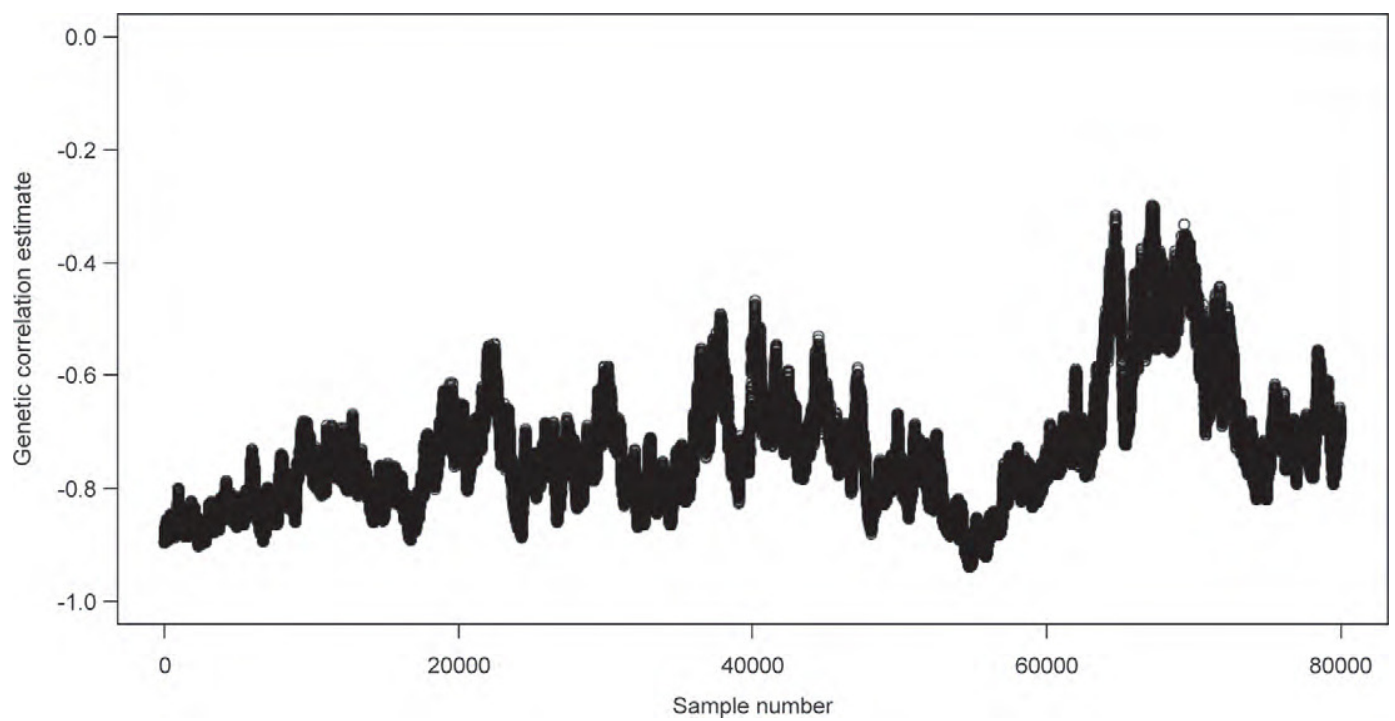

Figure 6. Estimates of the average daily genetic correlation between BCS and mastitis by round of Gibbs sampling (posterior mean $=-0.730$ and posterior standard deviation $=0.110$ ).

calculated using genetic (co)variance estimates from every fifth round of the Gibbs sampler. The average daily genetic correlation between BCS and metabolic disease was $-0.438(0.125)$. Daily genetic correlations between BCS and metabolic disease are shown in Figure 7. Daily estimates of genetic correlations between BCS and metabolic disease were moderate and consistent (between -0.40 and -0.45 ) throughout the lactation.

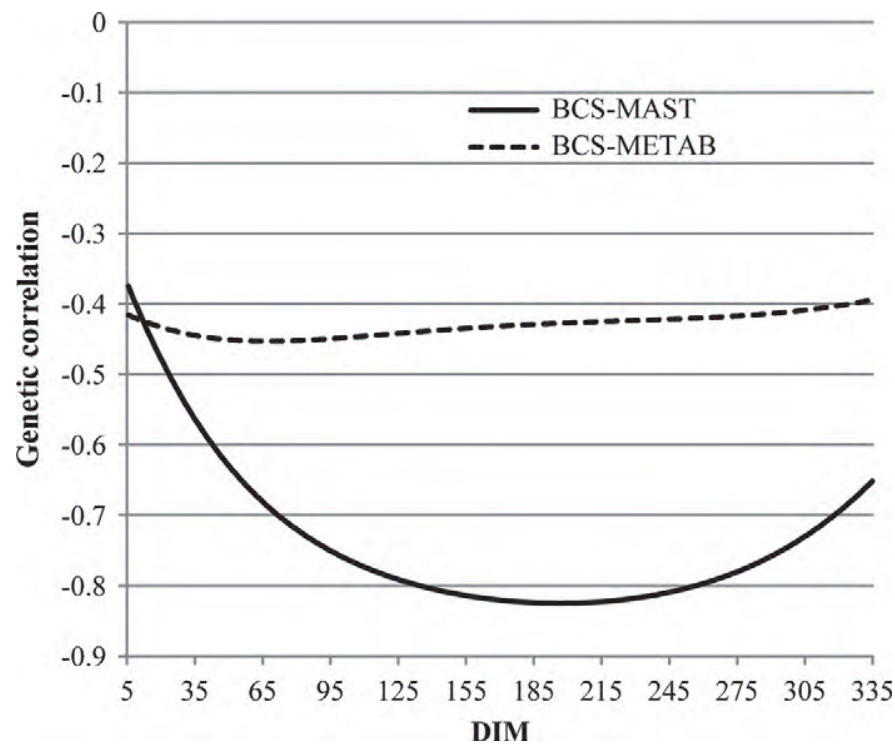

Figure 7. Estimates of daily genetic correlations between BCS, and mastitis (MAST) and metabolic disease (METAB) in firstlactation Canadian Holsteins. Posterior standard deviations were 0.110 (MAST) and 0.125 (METAB).
Neuenschwander (2010) obtained a genetic correlation between BCS and metabolic disease (defined as leftdisplaced abomasum, milk fever, and ketosis) occurrence of almost -0.30 between 3 and 5 mo of lactation, and the correlation was weaker at the beginning (approximately -0.20) and at the end (as strong as -0.10) of lactation. Koeck et al. (2011a) obtained a genetic relationship with $\mathrm{BCS}$ of $-0.40(\mathrm{SE}=0.08)$ and $-0.52(\mathrm{SE}=0.11)$ for displaced abomasum and ketosis, respectively.

Linear animal models were used to describe mastitis and metabolic disease, although the traits were binary. The use of linear models is typical for genetic evaluations of Canadian Holsteins, even with binary traits (Interbull, 2012). Threshold models for binary or categorical data have been shown to be more correct than linear models (Gianola, 1982); however, linear models may be preferred for numerous reasons (Jamrozik et al., 2005). Although heritabilities are usually higher using threshold models (Weigel and Rekaya, 2000; Mark, 2004; Neuenschwander, 2010), the literature indicates they have little effect on the ranking of animals between these models (Ramirez-Valverde et al., 2001; Jamrozik et al., 2005). Negussie et al. (2008a) evaluated clinical mastitis in bivariate analyses with continuous traits by using either a threshold-linear or linear-linear model and found similar estimates of genetic correlations for the 2 model types. Threshold models tend to experience "extreme category problems," in which observations for some subclasses are in the same category, which can cause convergence difficulty (Misztal et al., 1989). Additionally, threshold models are computationally more 


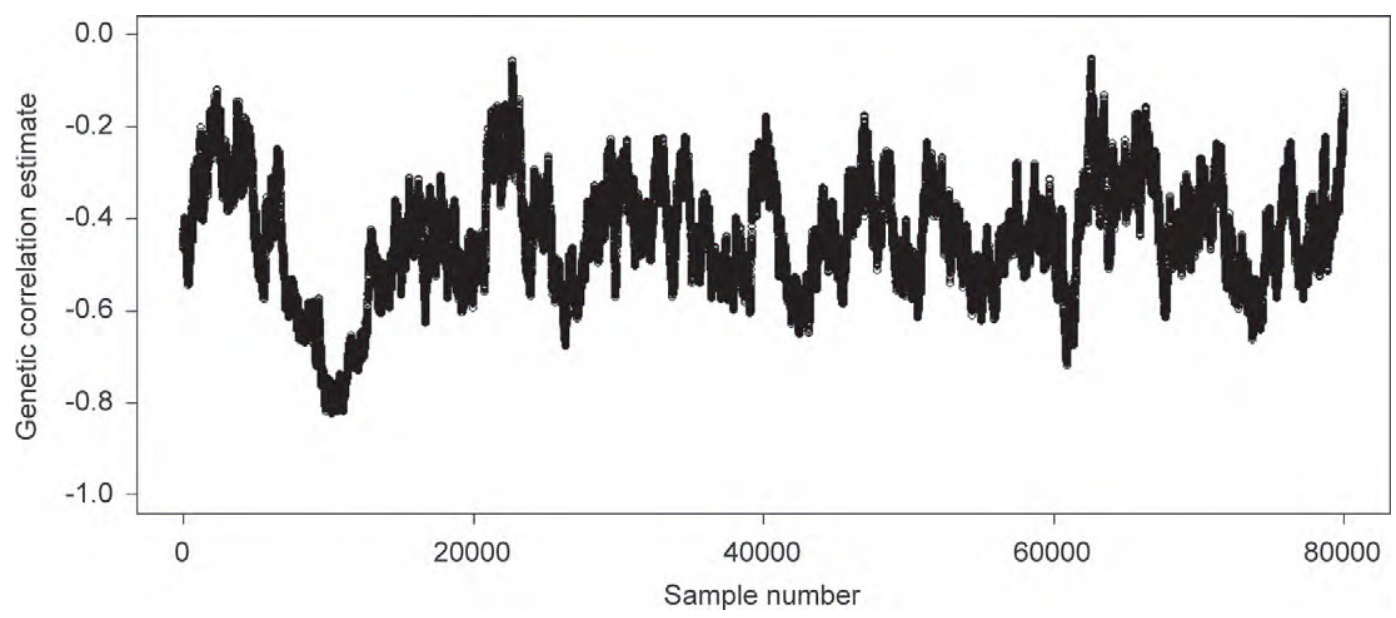

Figure 8. Estimates of average daily genetic correlation between BCS and metabolic disease (displaced abomasum, milk fever, and ketosis) by round of Gibbs sampling (posterior mean $=-0.438$ and posterior standard deviation $=0.125$ ).

involved than linear prediction in the observable scale (Meijering and Gianola, 1985; Misztal et al., 1989). For the reasons stated above, threshold models were not used to describe the health traits in this study.

Cows that mobilize more tissue are more likely to suffer from periparturient disease (Treacher et al., 1986; Seifi et al., 2007) because of impaired immune function (Goff and Horst, 1997). Lacetera et al. (2005) found that cows that were overconditioned (BCS $\geq 3.5$ on a 5-point scale) at calving experienced increased loss in BCS and impaired immune function in early lactation compared with cows that were medium conditioned (BCS 2.6 to 3.4 ) or thin (BCS $\leq 2.5$ ) at calving. Impaired immune function that is associated with excessive tissue mobilization and a lower BCS in early lactation would increase the risk of mastitis and other diseases. A study by Collard et al. (2000) determined that a longer, more extreme period of negative energy balance was associated with digestive (including displaced abomasum, milk fever, and ketosis) and locomotion problems. Alternatively or additionally, immune challenges may influence lipid metabolism (Bewley and Schutz, 2008) such that mastitis or metabolic disease could have a negative influence on BCS. In fact, the negative genetic correlation between mastitis and BCS after 150 DIM (Figure 7) is based on mastitis records taken before 150 DIM and BCS records taken after 150 DIM, and therefore might represent the effect of mastitis on BCS. Similarly, the negative genetic correlation between metabolic disease occurrence and BCS after 50 DIM could represent the effect of metabolic disease on BCS. In any case, given the distribution of data in the current study, the daily genetic correlation estimates between BCS and health traits may not be very reliable for the late part of lactation and should be interpreted with caution.

Indicator traits are gaining more attention, especially those that are easier to record; these can be measured early in life and are strongly genetically correlated with health and fertility traits (Berry et al., 2003a). A multitude of literature exists (some of which used the BCS data from Valacta) verifying that BCS is moderately to strongly genetically correlated with various health (Dechow et al., 2004; Neuenschwander, 2010) and reproduction traits (Pryce et al., 2001; Banos and Coffey, 2010; Bastin et al., 2010a,b). The consensus is that cows that mobilize more tissue (and experience a lower BCS during lactation) are more susceptible to health and fertility problems. One future possibility is to use BCS as a predictor of breeding values for health traits such as mastitis, fertility traits, or both. Alternatively, selection for BCS could have an indirect, positive effect on numerous traits, including reduced mastitis and metabolic disease occurrence.

\section{ACKNOWLEDGMENTS}

The authors acknowledge the DairyGen Council of the Canadian Dairy Network (Guelph, ON, Canada), the Natural Sciences and Engineering Research Council of Canada (Ottawa, ON, Canada), and Agriculture and Agri-Food Canada (Guelph, ON, Canada) for funding this project. The authors thank N. Gengler at the University of Liège, Belgium, for his advice regarding the model used in this analysis. Additionally, thanks are given to the producers for the recording of health events, which made this project possible. 


\section{REFERENCES}

Banos, G., and M. P. Coffey. 2010. Genetic association between body energy measured throughout lactation and fertility in dairy cattle. Animal 4:189-199.

Bastin, C., S. Loker, N. Gengler, A. Sewalem, and F. Miglior. 2010a. Genetic relationships between body condition score and reproduction traits for Canadian Holstein and Ayrshire first-parity cows. J. Dairy Sci. 93:2215-2228.

Bastin, C., S. Loker, N. Gengler, A. Sewalem, and F. Miglior. 2010b. Short communication: Genetic relationship between calving traits and body condition score before and after calving in Canadian Ayrshire second-parity cows. J. Dairy Sci. 93:4398-4403.

Beam, S. W., and W. R. Butler. 1997. Energy balance and ovarian follicle development prior to the first ovulation postpartum in dairy cows receiving three levels of dietary fat. Biol. Reprod. 56:133-142.

Berry, D. P., F. Buckley, and P. Dillon. 2007. Body condition score and live-weight effects on milk production in Irish Holstein-Friesian dairy cows. Animal 1:1351-1359.

Berry, D. P., F. Buckley, P. Dillon, R. D. Evans, M. Rath, and R. F. Veerkamp. 2003a. Genetic relationships among body condition score, body weight, milk yield, and fertility in dairy cows. J. Dairy Sci. 86:2193-2204.

Berry, D. P., F. Buckley, P. Dillon, R. D. Evans, M. Rath, and R. F. Veerkamp. 2003b. Genetic parameters for body condition score, body weight, milk yield, and fertility estimated using random regression models. J. Dairy Sci. 86:3704-3717.

Bewley, J. M., and M. M. Schutz. 2008. Review: An interdisciplinary review of body condition scoring for dairy cattle. Prof. Anim. Sci. 24:507-529.

Butler-Hogg, B. W., J. D. Wood, and J. A. Bines. 1985. Fat partitioning in British Friesian cows: The influence of physiological state on dissected body composition. J. Agric. Sci. 104:519-528.

Collard, B. L., P. J. Boettcher, J. C. M. Dekkers, D. Petitclerc, and L. R. Schaeffer. 2000. Relationships between energy balance and health traits of dairy cattle in early lactation. J. Dairy Sci. 83:2683-2690

Dal Zotto, R., M. De Marchi, C. Dalvit, M. Cassandro, L. Gallo, P. Carnier, and G. Bittante. 2007. Heritabilities and genetic correlations of body condition score and calving interval with yield, somatic cell score, and linear type traits in Brown Swiss cattle. J. Dairy Sci. 90:5737-5743.

Dechow, C. D., G. W. Rogers, U. Sander-Nielsen, L. Klei, T. J. Lawlor, J. S. Clay, A. E. Freeman, G. Abdel-Azim, A. Kuck, and S. Schnell. 2004. Correlations among body condition scores from various sources, dairy form, and cow health from the United States and Denmark. J. Dairy Sci. 87:3526-3533.

Dillon, P. 2006. A comparison of different dairy cow breeds on a seasonal grass-based system of milk production. 2. Reproduction and survival. Livest. Prod. Sci. 83:35-42.

Diskin, M. G., D. R. Mackey, J. F. Roche, and J. M. Sreenan. 2003. Effects of nutrition and metabolic status on circulating hormones and ovarian follicle development in cattle. Anim. Reprod. Sci. 78:345-370.

Edmonson, A. J., I. J. Lean, L. D. Weaver, T. Farver, and G. Webster. 1989. A body condition scoring chart for Holstein dairy cows. J. Dairy Sci. 72:68-78.

Emanuelson, U., B. Danell, and J. Philipsson. 1988. Genetic parameters for clinical mastitis, somatic cell counts, and milk production estimated by multiple-trait restricted maximum likelihood. J. Dairy Sci. 71:467-476.

Enevoldsen, C., and T. Kristensen. 1997. Estimation of body weight from body size measurements and body condition scores in dairy cows. J. Dairy Sci. 80:1988-1995.

Ferguson, J. D., D. T. Galligan, and N. Thomsen. 1994. Principal descriptors of body condition score in Holstein cows. J. Dairy Sci. 77:2695-2703.

Gearhart, M. A., C. R. Curtis, H. N. Erb, R. D. Smith, C. J. Sniffen, L. E. Chase, and M. D. Cooper. 1990. Relationship of changes in condition score to cow health in Holsteins. J. Dairy Sci. 73:31323140 .

Gianola, D. 1982. Theory and analysis of threshold characters. J. Anim. Sci. 54:1079-1096.

Goff, J. P., and R. L. Horst. 1997. Physiological changes at parturition and their relationship to metabolic disorders. J. Dairy Sci. 80:1260-1268.

Gregory, N. G., J. K. Robins, D. G. Thomas, and R. W. Purchas. 1998. Relationship between body condition score and body composition in dairy cows. N. Z. J. Agric. Res. 41:527-532.

Grummer, R. R. 1993. Etiology of lipid-related metabolic disorders in periparturient dairy cows. J. Dairy Sci. 76:3882-3896.

Harrison, R. O., S. P. Ford, J. W. Young, A. J. Conley, and A. E. Freeman. 1990. Increased milk production versus reproductive and energy status of high producing dairy cows. J. Dairy Sci. 73:2749-2758.

Heringstad, B., Y. M. Chang, D. Gianola, and G. Klemetsdal. 2003. Genetic analysis of longitudinal trajectory of clinical mastitis in first-lactation Norwegian Cattle. J. Dairy Sci. 86:2676-2683.

Hüttmann, H., E. Stamer, W. Junge, G. Thaller, and E. Kalm. 2009. Analysis of feed intake and energy balance of high-yielding first lactating Holsetin cows with fixed and random regression models. Animal 3:181-188.

Interbull. 2012. Description of national genetic evaluation systems for dairy cattle traits as applied in different Interbull member countries. International Bull Evaluation Service, Uppsala, Sweden. Accessed June 8, 2012. http://www.interbull.org.

Jamrozik, J., J. Fatehi, G. J. Kistemaker, and L. R. Schaeffer. 2005. Estimates of genetic parameters for Canadian Holstein female reproduction traits. J. Dairy Sci. 88:2199-2208.

Jones, H. E., I. M. S. White, and S. Brotherstone. 1999. Genetic evaluation of Holstein Friesian sires for daughter condition-score changes using a random regression model. Anim. Sci. 68:467-475.

Kadarmideen, H. N., and M. P. Coffey. 2001. Quality and validation of insemination data for national genetic evaluations for dairy cow fertility in the United Kingdom. Proceedings of the Interbull Meeting, Budapest, Hungary. Interbull Bull. 27:133-138.

Koeck, A., F. Miglior, D. F. Kelton, and F. S. Schenkel. 2011a. Genetic association between body condition score and disease resistance in first lactation Canadian Holsteins. Sept. Dairy Cattle Breed. Genet. Comm. Mtg. Accessed Aug. 28, 2012. http://cgil.uoguelph. ca/dcbgc/Agenda1109/Paper2_Genetic\%20association\%20between $\% 20$ body $\% 20$ condition $\% 20$ score\%20and\%20disease\%20resistance\%20in\%20first\%20lactation\%20Canadian\%20Holsteins.pdf.

Koeck, A., F. Miglior, D. F. Kelton, and F. S. Schenkel. 2011b. Multiple-trait model for mastitis resistance in Canadian Holsteins: A preliminary investigation. Sept. Dairy Cattle Breed. Genet. Comm. Mtg. Accessed Aug. 28, 2012. http://cgil.uoguelph.ca/dcbgc/Agenda1109/Paper3_Multiple\%20trait\%20model\%20for $\% 20$ mastitis\%20resistance\%20in\%20Canadian\%20Holsteins\%20A\%20 preliminary\%20investigation.pdf.

Koeck, A., F. Miglior, D. F. Kelton, and F. S. Schenkel. 2012a. Alternative somatic cell count traits to improve mastitis resistance in Canadian Holsteins. J. Dairy Sci. 95:432-439.

Koeck, A., F. Miglior, D. F. Kelton, and F. S. Schenkel. 2012b. Health recording in Canadian Holsteins - Data and genetic parameters. J. Dairy Sci. 95:4099-4108.

Koenen, E. P. C., R. F. Veerkamp, P. Dobbelaar, and G. De Jong. 2001. Genetic analysis of body condition score of lactating Dutch Holstein and Red-and-White heifers. J. Dairy Sci. 84:1265-1270.

Kristensen, E., L. Dueholm, D. Vink, J. E. Andersen, E. B. Jakobsen, S. Illum-Nielsen, F. A. Petersen, and C. Enevoldsen. 2006. Withinand across-person uniformity of body condition scoring in Danish Holstein cattle. J. Dairy Sci. 89:3721-3728.

Lacetera, N., D. Scalia, U. Bernabucci, B. Ronchi, D. Pirazzi, and A. Nardone. 2005. Lymphocyte functions in overconditioned cows around parturition. J. Dairy Sci. 88:2010-2016.

Lassen, J., M. Hansen, M. K. Sørensen, G. P. Aamand, L. G. Christensen, and P. Madsen. 2003. Genetic relationship between body condition score, dairy character, mastitis, and diseases other 
than mastitis in first-parity Danish Holstein cows. J. Dairy Sci. $86: 3730-3735$.

Loker, S., C. Bastin, F. Miglior, A. Sewalem, L. R. Schaeffer, J. Jamrozik, A. Ali, and V. Osborne. 2012. Genetic and environmental relationships between body condition score and milk production traits in Canadian Holsteins. J. Dairy Sci. 95:410-419.

Loker, S., C. Bastin, F. Miglior, A. Sewalem, L. R. Schaeffer, J. Jamrozik, and V. Osborne. 2011. Short communication: Estimates of genetic parameters of body condition score in the first 3 lactations using a random regression animal model. J. Dairy Sci. 94:36933699.

Madsen, P., and J. Jensen. 2008. A User's Guide to DMU: A Package for Analysing Multivariate Mixed Models. Version 6, release 4.7 . Research Centre Foulum, Tjele, Denmark. Accessed Jul. 25, 2012. http://www.dmu.agrsci.dk/dmuv6_guide-R4-6-7.pdf.

Mao, I. L., K. Sloniewski, P. Madsen, and J. Jensen. 2004. Changes in body condition score and in its genetic variation during lactation. Livest. Prod. Sci. 89:55-65.

Mark, T. 2004. Applied genetic evaluations for production and functional traits in dairy cattle. J. Dairy Sci. 87:2641-2652.

Meijering, A., and D. Gianola. 1985. Observations on sire evaluation with categorical data using heteroscedastic mixed linear models. J. Dairy Sci. 68:1226-1232.

Miglior, F., B. L. Muir, and B. J. Van Doormaal. 2005. Selection indices in Holstein cattle of various countries. J. Dairy Sci. 88:12551263.

Misztal, I., D. Gianola, and J. L. Foulley. 1989. Computing aspects of a nonlinear method of sire evaluation for categorical data. J. Dairy Sci. 72:1557-1568.

Negussie, E., I. Strandén, and E. A. Mäntysaarl. 2008a. Genetic analysis of liability to clinical mastitis, with somatic cell score and production traits using bivariate threshold-linear and linear-linear models. Livest. Sci. 117:52-59.

Negussie, E., I. Strandén, and E. A. Mäntysaarl. 2008b. Genetic association of clinical mastitis with test-day somatic cell score and milk yield during first lactation of Finnish Ayrshire cows. J. Dairy Sci. 91:1189-1197.

Neuenschwander, T. F.-O. 2010. Studies on disease resistance based on producer-recorded data in Canadian Holsteins. PhD Thesis. University of Guelph, Guelph, ON, Canada.

Neuenschwander, T. F.-O., F. Miglior, J. Jamrozik, O. Berke, D. F. Kelton, and L. R. Schaeffer. 2012. Genetic parameters for producer-recorded health data in Canadian Holstein cattle. Animal 6:571-578.

Pryce, J. E., M. P. Coffey, and G. Simm. 2001. The relationship between body condition score and reproductive performance. J. Dairy Sci. 84:1508-1515.

Ramirez-Valverde, R., I. Misztal, and J. K. Bertrand. 2001. Comparison of threshold vs. linear and animal vs sire models for predicting direct and maternal genetic effects on calving difficulty in beef cattle. J. Anim. Sci. 79:333-338.

Roche, J. R., P. G. Dillon, C. R. Stockdale, L. H. Baumgard, and M. J. VanBaale. 2004. Relationships among international body condition scoring systems. J. Dairy Sci. 87:3076-3079.
Roche, J. R., N. C. Friggens, J. K. Kay, M. W. Fisher, K. J. Stafford, and D. P. Berry. 2009. Invited review: Body condition score and its association with dairy cow productivity, health, and welfare. J. Dairy Sci. 92:5769-5801.

Ruegg, P. L., and R. L. Milton. 1995. Body condition scores of Holstein cows on Prince Edward Island, Canada: Relationships with yield, reproductive performance and disease. J. Dairy Sci. 78:552-564.

Schröder, U. J., and R. Staufenbiel. 2006. Invited review: Methods to determine body fat reserves in the dairy cow with special regard to ultrasonographic measurement of backfat thickness. J. Dairy Sci. 89:1-14.

Searle, S. R. 1982. Matrix Algebra Useful for Statistics. John Wiley \& Sons Inc., New York, NY.

Seifi, H. A., S. J. LeBlanc, E. Vernooy, K. E. Leslie, and T. F. Duffield. 2007. Effect of isoflupredone acetate with or without insulin on energy metabolism, reproduction, milk production, and health in dairy cows in early lactation. J. Dairy Sci. 90:4181-4191.

Shook, G. E. 1989. Selection for disease resistance. J. Dairy Sci $72: 1349-1362$.

Treacher, R. J., I. M. Reid, and C. J. Roberts. 1986. Effect of body condition at calving on the health and performance of dairy cows. Anim. Prod. 43:1-6.

Veerkamp, R. F., E. P. C. Koenen, and G. de Jong. 2001. Genetic correlations among body condition score, yield, and fertility in first-parity cows estimated by random regression models. J. Dairy Sci. 84:2327-2335

Veerkamp, R.F., J.K. Oldenbroek, H.J. Van Der Gaast, and J.H.J. Van Der Werf. 2000. Genetic correlation between days until start of luteal activity and milk yield, energy balance, and live weights. J. Dairy Sci. 83:577-583.

Wall, E., S. Brotherstone, J. A. Woolliams, G. Banos, and M. P. Coffey. 2003. Genetic evaluation of fertility using direct and correlated traits. J. Dairy Sci. 86:4093-4102.

Waltner, S. S., J. P. McNamara, J. K. Hillers, and D. L. Brown. 1994 Validation of indirect measures of body fat in lactating cows. J Dairy Sci. $77: 2570-2579$

Ward, W. R. 2003. Body condition scoring-Technique and application. Cattle Pract. 11:111-115.

Wathes, D. C., M. Fenwick, Z. Cheng, N. Bourne, S. Llewellyn, D. G. Morris, D. Kenny, J. Murphy, and R. Fitzpatrick. 2007. Influence of negative energy balance on cyclicity and fertility in the high producing dairy cow. Theriogenology 68(Suppl. 1):S232-S241.

Weigel, K. A., and R. Rekaya. 2000. Genetic parameters for reproductive traits of Holstein cattle in California and Minnesota. J. Dairy Sci. 83:1072-1080.

Wildman, E. E., G. M. Jones, P. E. Wagner, R. L. Boman, H. F. Troutt Jr., and T. N. Lesch. 1982. A dairy cow body condition scoring system and its relationship to selected production characteristics. J. Dairy Sci. 65:495-501.

Wright, I. A., and A. J. F. Russel. 1984. Partition of fat, body composition and body condition score in mature cows. Anim. Prod. $38: 23-32$. 